\title{
Effects of controllability of stress on hippocampal pharmacology
}

\author{
CARA L. WELLMAN \\ Indiana University, Bloomington, Indiana \\ and \\ MARY JANE CULLEN and MARY ANN PELLEYMOUNTER \\ Amgen, Inc., Thousand Oaks, Califormia
}

\begin{abstract}
To examine the effect of the controllability of stress on aspects of hippocampal noradrenergic, opiate, and cholinergic pharmacology, we trained rats in a controllability paradigm and assessed $\left[{ }^{3} \mathrm{H}\right]$ desmethylimipramine, $\left[{ }^{3} \mathrm{H}\right]$ quinuclidinyl benzilate, or $\left[{ }^{3} \mathrm{H}\right]$ naloxone binding in hippocampal areas $\mathrm{CA} 1, \mathrm{CA} 3$, and the dentate gyrus with quantitative autoradiography. Rats that could control shock termination were yoked to rats that could not control termination of equivalent shock; a third group of rats received no shock. When the rats that could terminate shock responded at an $85 \%$ rate, their brains were removed and sectioned, incubated with tritiated ligands, and exposed to film for an appropriate period. Quantitative densitometry revealed a 10\%-22\% decrease in naloxone binding in CA3 in rats receiving uncontrollable shock; no significant changes were observed in rats that could control shock. Thus, the ability to control shock prevented stress-induced changes in $\mu$ opiate receptor binding in area CA3 of the hippocampus.
\end{abstract}

Uncontrollable stress produces a variety of cognitive alterations. For instance, although exposure to uncontrollable stress facilitates performance in some classical conditioning paradigms (see, e.g., Servatius \& Shors, 1994; Shors, Weiss, \& Thompson, 1992), it has also been shown to produce deficits on subsequent shuttle-escape tasks (see, e.g., Overmier \& Seligman, 1967; Seligman \& Maier, 1967 ) as well as on water maze tasks (Altenor, Kay, \& Richter, 1977). Furthermore, the cognitive deficits produced by exposure to uncontrollable shock are not limited to aversively motivated tasks. For instance, exposure to uncontrollable shock impaired acquisition of either a leverpress or a nose-poke response for food reinforcement (Rosellini, 1978; Rosellini \& DeCola, 1981). More recently, Luine and colleagues (Luine, Villegas, Martinez, $\&$ McEwen, 1994) found that chronic exposure to uncontrollable restraint stress produced deficits on an appetitively motivated radial maze task. These deficits, termed learned helplessness, do not occur if animals can control termination of the stressor (Seligman \& Maier, 1967).

Cognitive deficits induced by learned helplessness may be mediated by concomitant alterations in the morphology, physiology, and pharmacology of the hippocampus, which is rich in glucocorticoid receptors that are involved in the stress response (Gerlach \& McEwen, 1972) and are important in learning and memory. Chronic restraint stress has been shown to result in atrophy of apical dendrites of pyra-

This research was supported by ADAMHA 5 RO3 MH49541-02 to M.A.P. M.J.C. and M.A.P. are in the Department of Neurobiology, Amgen, Inc. Correspondence concerning this article should be addressed to C. L. Wellman, Department of Psychology, Indiana University, Bloomington, IN 47405 (e-mail: wellmanc@indiana.edu). midal neurons in area $\mathrm{CA} 3$ of the hippocampus (Watanabe, Gould, \& McEwen, 1992). Furthermore, others have shown that exposure to uncontrollable shock produces deficits in long-term potentiation (LTP) in CAl (Shors, Seib, Levine, \& Thompson, 1989) and alterations in hippocampal theta activity (Balleine \& Curthoys, 1991). Both restraint stress and uncontrollable shock altered granule cell evoked potentials in the dentate gyrus, and these changes correlated with the presence of ulcers and deficits on a subsequent shuttle escape task (Henke, 1990).

In addition, the hippocampal noradrenergic, cholinergic, and opiate systems are altered after uncontrollable stress. For instance, exposure to uncontrollable shock impaired choice-escape learning and depleted hippocampal norepinephrine concentrations after shock reexposure; lesions of the ascending dorsal tegmental bundle produced the same behavioral deficits, suggesting that depletion of hippocampal norepinephrine may be responsible for the deficit in choice-escape learning (Minor, Pelleymounter, \& Maier, 1988). Using microdialysis, Petty and colleagues (Petty, Kramer, Wilson, \& Chae, 1993) showed that, after uncontrollable stress, $\mathrm{K}^{+}$-stimulated norepinephrine release in the hippocampus was attenuated in rats that demonstrated learned helplessness. This decrease in presynaptic norepinephrine may produce a compensatory increase in $\beta$-adrenergic receptors: Rats that demonstrated learned helplessness on a shuttle-escape task after an acute exposure to footshock showed increased $\beta$-adrenergic receptor binding in the hippocampus, as compared with either nonlearned-helpless or no-shock controls (Martin, Edwards, Johnson, \& Henn, 1990).

Uncontrollable stress also alters the septohippocampal cholinergic system. For instance, acute immobiliza- 
tion stress increased hippocampal choline uptake and acetylcholine release immediately following the stressor, whereas chronic immobilization stress produced an increase in both acetylcholine release and muscarinic receptor binding, along with a decrease in choline uptake (Finkelstein, Koffler, Rabey, \& Gilad, 1985). A subsequent quantitative autoradiographic study indicated that acute stress-induced increases in muscarinic cholinergic receptor binding occur in several hippocampal fields; however, the increase in binding in the dentate gyrus appears to be more long-lasting than that in area CA1-CA2 (Mizukawa et al., 1989). Lesions of the medial septum ameliorated the escape deficits produced by uncontrollable shock, which suggests that learned helplessness is mediated in part by cholinergic afferents to the hippocampus (Kelsey \& Baker, 1983).

Finally, the opiate system, which supplies afferents to hippocampal pyramidal neurons (Gall, Brecha, Karten, \& Chang, 1981), has been repeatedly implicated in the effects of stress on both behavior and hippocampal function. For example, $\mu$ opiate receptor blockade via naloxone has been shown to both facilitate learned helplessness and block imipramine's ability to reverse learned helplessness (Tejedor-Real, Mico, Maldonado, Roques, \& GibertRahola, 1995; but see Shors, Levine, \& Thompson, 1990).

Whereas ability to control the stressor ameliorates both the behavioral (see, e.g., Overmier \& Seligman, 1967) and the physiological (see, e.g., Balleine \& Curthoys, 1991; Shors et al., 1989) sequelae of stress, the comparison in assessing the pharmacological effects of stress is typically between those animals receiving uncontrollable shock and those receiving no shock at all. Thus, although the pharmacological correlates of uncontrollable stress have been studied extensively (see, e.g., Finkelstein et al., 1985; Petty et al., 1993; Tejedor-Real et al., 1995), the impact of controllability of stress on the pharmacology of brain areas mediating potential cognitive changes is not well characterized.

In this study, we examined the hypothesis that control over the stressor might alter the pattern of pharmacological changes seen in the hippocampus after uncontrollable stress. The noradrenergic, opiate, and cholinergic systems play an interactive role in learning and memory. For instance, the opiate system plays a role in hippocampally mediated learning and memory tasks (see, e.g., Gallagher, King, \& Young, 1983), and the noradrenergic and opiate systems have an interactive effect on aspects of learning and memory mediated by the amygdala (Gallagher, Rapp, \& Fanelli, 1985). Likewise, the noradrenergic and cholinergic systems have extensive interactions in the amygdala, neocortex, and hippocampus (Bear \& Singer, 1986; Dalmaz, Introini-Collison, \& McGaugh, 1993; Kruglikov, 1982; also see the review by Decker, 1992). Finally, studies indicate that $\mu$ opiate receptors play a role in hippocampal acetylcholine release (Pasternak, 1987). Thus, these systems may play a role in hippocampally mediated, stress-induced cognitive deficits. Therefore, we subjected rats to a chronic course of con- trollable, uncontrollable, or no shock. Subsequently, half of the rats in each group were tested in a shuttle-escape task in order to assess the ability of this manipulation to produce learned helplessness. To eliminate the possibility that uniform exposure to the escapable shock employed in the shuttle task would obscure potential neurochemical differences across the three experimental groups, the other half were used to assess noradrenergic uptake sites, muscarinic cholinergic receptor binding, and $\mu$ opiate receptor binding in hippocampal areas CA1, CA3, and the dentate gyrus using in vitro autoradiography.

\section{METHOD}

\section{Animals}

Male Long-Evans rats weighing $175-200 \mathrm{~g}(N=48$; Harlan Sprague-Dawley, Indianapolis, IN) were subjected to controllability training. The rats were individually housed in a vivarium with a 12-h light:dark cycle, an ambient temperature of $23^{\circ}-25^{\circ} \mathrm{C}$, and free access to food and water. All experimental procedures occurred between i0:00 a.m. and 2:00 p.m.

\section{Controllability Training}

Apparatus. The rats were trained in operant chambers $(33 \mathrm{~cm} \times$ $30.5 \mathrm{~cm} \times 25.4 \mathrm{~cm}$; Coulbourn Instruments, Allentown, PA) consisting of Plexiglas sidewalls and ceiling, stainless steel front and rear walls, and grid floors. Each chamber was equipped with a stainless steel lever $(3.8 \mathrm{~cm}$ wide $\times 1.9 \mathrm{~cm}$ deep) located $2.5 \mathrm{~cm}$ above the grid floor in the middle of the side panel. In addition, a houselight was positioned $27.9 \mathrm{~cm}$ above the floor on the back panel of the operant chamber. Scrambled constant-current shocks (1.0 mA) were delivered through the stainless steel bars of the grid floor with a Coulbourn E13-12 scrambled shocker.

Procedure. The rats that could terminate shock (controllable shock group, CS; $n=16$ ) were yoked to rats that could not terminate equivalent shock (uncontrollable shock group, US; $n=16$ ); a group of control rats did not receive shock (no-shock group, NS; $n=16$ ). The rats in the CS group were placed in operant chambers and received $1-\mathrm{mA}$ scrambled footshocks that could be terminated with a single leverpress. Thirty shocks per session were administered at intervals of $60 \mathrm{sec}$. Shock was automatically terminated if a leverpress did not occur within $60 \mathrm{sec}$. The shock schedule of each of the US rats was yoked to that of a CS partner. Thus, each US rat received the same number and duration of shocks as did a CS rat. A lever was present in the chamber of each US rat, but a leverpress did not terminate shock. Additionally, NS rats were placed in operant chambers during the controllability training sessions but did not receive shocks.

All rats received controllability training for at least two sessions. Controllability training ended when a CS rat responded with a leverpress within $1.5 \mathrm{sec}$ on at least $85 \%$ of the trials and its US partner made fewer than 10 leverpresses. Twenty-four hours after reaching criterion, half of the rats in each group were tested on a shuttleescape learning task. The other half were decapitated, and their brains were processed for autoradiography.

\section{Behavioral Testing}

Apparatus. The rats were tested in stainless steel shuttle boxes $(25.4 \times 35.6 \times 17.8 \mathrm{~cm}$; Coulbourn Instruments) divided into two equal compartments by a panel containing a guillotine door $(8.9 \times$ $6.4 \mathrm{~cm}$ ). A houselight was positioned $27.9 \mathrm{~cm}$ above the floor on the back panel of one compartment of the shuttle box. As in the controllability training, 1.0-mA scrambled constant-current shocks were delivered through the grid floor with a Coulbourn E13-12 scrambled shocker. 
Procedure. To assess whether the manipulation used in the present study produced learned helplessness, the rats were tested in a shuttle-escape learning task $24 \mathrm{~h}$ after the final controllability session. Each rat was placed in the shuttle box and given 30 trials in which it received a $1.0-\mathrm{mA}$ footshock that could be terminated by crossing to the opposite side of the box. All trials were unsignaled and separated by a $60-\mathrm{sec}$ intertrial interval. Each rat received 5 FR 1 trials, in which shock could be terminated with one crossing, followed by 25 FR2 trials, in which shock was terminated after two crossings. Shock was automatically terminated if an appropriate response did not occur within $60 \mathrm{sec}$. Escape latencies were recorded and compared across the three treatment groups with a one-way analysis of variance (ANOVA) and Fisher's protected least significant difference (LSD) post hoc comparisons.

\section{Autoradiography}

Twenty-four hours after reaching training criteria, the rats were exposed to the operant chambers with houselights on for $1 \mathrm{~min}$. Approximately $6 \mathrm{~min}$ later, the rats were decapitated, and their brains were rapidly removed, frozen in isopentane, and stored at $-80^{\circ} \mathrm{C}$. The brains were cut at $16 \mu \mathrm{m}$ in a cryostat and thaw-mounted on chrome-alum gelatin-coated slides. For each ligand, six equally spaced sections through the dorsal hippocampus were saved. Total binding was assessed in three of these sections, whereas nonspecific binding was determined in three anatomically adjacent sections. All tritiated ligands were supplied by NEN (Boston, MA); all unlabeled competitors were supplied by Sigma (St. Louis, MO).

To label muscarinic receptors, sections were rinsed for $3 \mathrm{~min}$ at $4^{\circ} \mathrm{C}$ in $.05 \mathrm{M}$ phosphate buffer ( $\mathrm{pH} 7.4$ ). To assess total binding, sections were incubated for $1 \mathrm{~h}$ at $4^{\circ} \mathrm{C}$ in buffer plus $1.5 \mathrm{nM}$ $\left[{ }^{3} \mathrm{H}\right]$ quinuclidinyl benzylate $(\mathrm{QNB}, 43.5 \mathrm{Ci} / \mathrm{mmol})$. Nonspecific binding was assessed by competing $\left[{ }^{3} \mathrm{H}\right] \mathrm{QNB}$ against $20 \mu \mathrm{M}$ atropine, and non- $\mathrm{M}_{1}$ receptor binding was assessed by competing $\left[{ }^{3} \mathrm{H}\right] \mathrm{QNB}$ against $2.0 \mu \mathrm{M}$ pirenzepine. Nonspecific binding of $\left[{ }^{3} \mathrm{H}\right]$ QNB averaged $2 \% \pm 0.4 \%$ over all hippocampal fields, which is consistent with previous reports (see, e.g., Nonaka \& Moroji, 1984). After two 3-min rinses at $4^{\circ} \mathrm{C}$ in buffer, slides were dipped in cold distilled $\mathrm{H}_{2} \mathrm{O}$ (see Nonaka \& Moroji, 1984).

To assess potential alterations in noradrenergic activity, noradrenergic reuptake sites were labeled with $\left[{ }^{3} \mathrm{H}\right]$ desmethylimipramine hydrochloride (DMI, $73 \mathrm{Ci} / \mathrm{mmol}$ ) using the procedure described by Rapp (1986). Sections were incubated in dim light for $1 \mathrm{~h}$ at $4^{\circ} \mathrm{C}$ in $50 \mathrm{mM}$ tris- $\mathrm{HCl}(\mathrm{pH} 7.4)$ plus $300 \mathrm{mM} \mathrm{NaCl}$ and $2.0 \mathrm{nM}\left[{ }^{3} \mathrm{H}\right] \mathrm{DMI}$. Nonspecific binding was assessed by competing against $100 \mu \mathrm{M}$ desipramine and averaged $52 \% \pm 3 \%$, which is consistent with previous studies (see, e.g., Duncan et al., 1991; Rapp, 1986). After three 20 -min rinses at $4^{\circ} \mathrm{C}$ in buffer, slides were dipped in cold distilled $\mathrm{H}_{2} \mathrm{O}$.

$\mathrm{Mu}$ opiate receptors were labeled using a procedure similar to that of Geary and Wooten (1983). Sections were incubated at $4^{\circ} \mathrm{C}$ for $1 \mathrm{~h}$ in buffer $(50 \mathrm{mM}$ tris- $\mathrm{HCl}, \mathrm{pH} \mathrm{7.4,} \mathrm{plus} 100 \mathrm{mM} \mathrm{NaCl})$ containing $2.5 \mathrm{nM}\left[{ }^{3} \mathrm{H}\right]$ naloxone $(55.5 \mathrm{Ci} / \mathrm{mmol})$. Nonspecific binding was assessed with $250 \mu \mathrm{M}$ naloxone. Consistent with previous studies (see, e.g., Geary \& Wooten, 1983), nonspecific binding averaged $12 \% \pm 2 \%$. Slides were rinsed six times ( $20 \mathrm{sec}$ each) in ice-cold phosphate-buffered saline ( $50 \mathrm{mM}$; pH 7.4).

All slides were dried in a stream of cold air, stored under vacuum with dessicant overnight, and then placed in autoradiographic cassettes (Hypercassettes; Amersham, Cleveland), exposed to film $\left({ }^{3} \mathrm{H}\right.$ Hyperfilm; Amersham) along with standardized autoradiographic microscales (Amersham), and stored at $-80^{\circ} \mathrm{C}$ for 4 weeks. The films were then developed (Kodak D-19), fixed (Kodak Fixer), and air dried. Slides were exposed to paraformaldehyde vapors and stained with cresylecht violet.

The density of binding in the hippocampal CA1 and CA3 fields and dentate gyrus of the resulting autoradiographic images was quantified with a computer-based image analysis system (MCID; Imaging Research Inc., St. Catharines, Ontario). Histological slides were placed on a light box (Northern Light; Imaging Research, Inc.) and digitized; the corresponding autoradiograms were then placed on the light box and digitized, and the computerized images were aligned with the histological section. Regions of interest were then defined on the histological sections, and samples were taken from the corresponding areas of the autoradiograms. For each ligand, average optical density was measured in the pyramidal cell layer, stratum oriens, and stratum radiatum of hippocampal CAl and CA3 and in the granule cell layer, molecular layer, and hilus of the dentate gyrus in each hemisphere of each section. Thus, nine total and nine nonspecific samples per animal were obtained. Measures were standardized against the microscales included on each film and expressed in $\mathrm{fmol} / \mathrm{mg}$ wet tissue weight. Specific binding was calculated by subtracting total binding from nonspecific binding for each pair of sections.

Density of specific binding of each ligand was then compared across CS, US, and NS rats using a multivariate ANOVA (MANOVA) followed by two-way ANOVAs (treatment $\times$ layer) and post hoc tests (Fisher's protected LSD) for each hippocampal field.

\section{RESULTS}

\section{Behavioral Testing}

Overall, the CS rats readily learned to barpress to escape shock, averaging $3.86 \pm .55$ days to reach the $85 \%$ criterion. Two CS rats failed to reach criterion after 10 days, and these rats, along with their yoked US and NS partners, were therefore excluded from subsequent analyses. Thus, 21 rats ( 7 per group) underwent shuttle-escape testing, whereas 21 rats ( 7 per group) were used for autoradiography.

To assess the efficacy of the controllability training, the rats were tested on a shuttle-escape task. Although escape latencies tended to be longer in both the CS and US groups with an FR1 schedule of reinforcement, a oneway ANOVA revealed that this difference was not significant $[F(2,18)=2.88$, n.s.]. However, a significant treatment effect was present during the FR2 reinforcement schedule $[F(2,18)=8.06, p<.05$; see Figure 1]. Post hoc analyses demonstrated that exposure to uncontrollable shock significantly impaired acquisition of the escape response. The rats receiving uncontrollable shock performed significantly worse on the FR2 schedule than did both the NS and the CS groups $[t(12)=14.56, p<$ .05 , and $t(12)=10.63, p<.05$, respectively]. However, CS rats were unimpaired on this task: The performance of CS rats did not differ significantly from that of NS rats $[t(12)=3.93$, n.s. $]$.

\section{Autoradiography}

The distribution of binding in the hippocampus of all ligands examined was similar to that reported in previous studies (see, e.g., Duncan et al., 1991; Herkenham \& Pert, 1980; Nonaka \& Moroji, 1984; Rapp, 1986). For all ligands, the density of binding varied across hippocampal fields (Figure 2). The distribution of $\left[{ }^{3} \mathrm{H}\right] \mathrm{QNB}$ binding in area CA1 was about twice that in CA3; the density of binding was intermediate in the dentate gyrus (Figure 2A). 


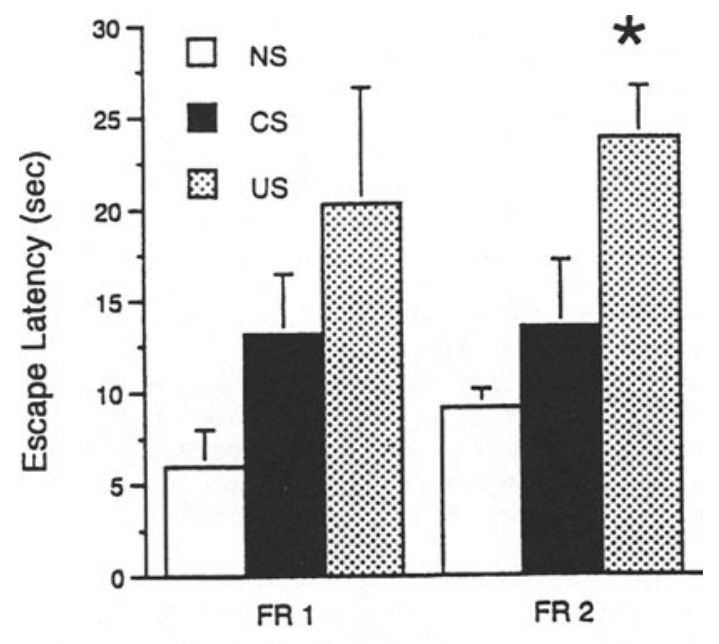

Reinforcement Schedule

Figure 1. Mean escape latencies for rats receiving no shock (NS), controllable shock (CS), or uncontrollable shock (US) on a shuttle-escape task with FR1 and FR2 schedules of reinforcement. Vertical bars represent error bars. The asterisk indicates a significant difference from NS and CS groups $(p<.05)$.

The highest density of $\left[{ }^{3} \mathrm{H}\right] \mathrm{DMI}$ binding occurred in the dentate gyrus and in $\mathrm{CA} 3$; the density of binding in $\mathrm{CA} 1$ was approximately half that in the dentate gyrus (Figure $2 \mathrm{~B}$ ). Finally, $\left[{ }^{3} \mathrm{H}\right]$ naloxone binding was most dense in area $\mathrm{CA} 3$, whereas binding in $\mathrm{CA} 1$ and the dentate gyrus was approximately $60 \%$ of that in CA3 (Figure 2C). In addition, for each ligand, the distribution of binding also varied across layers within each hippocampal field examined [for effect of layer assessed with a MANOVA for each ligand, all $F \mathrm{~s}(6,104) \geq 5.94, p<.05]$.

Chronic exposure to either controllable or uncontrollable shock failed to significantly alter either muscarinic receptor binding or noradrenergic uptake in any hippocampal field: A two-way MANOVA revealed no significant effect of treatment $[F(18,92)=.76$, n.s.; Figure 3] on total $\left[{ }^{3} \mathrm{H}\right] \mathrm{QNB}$ binding, $\mathrm{M} 1$, or non-M1 receptor binding. Furthermore, exposure did not appear to affect binding in specific layers, as the interactive effect of treatment and layer was also nonsignificant $[F(36,174)=.66$, n.s.]. Likewise, a two-way MANOVA revealed no significant effect of group on $\left[{ }^{3} \mathrm{H}\right] \mathrm{DMI}$ binding either overall $[F(6,104)=1.84$, n.s.; Figure 4$]$ or in specific layers $[F(12,138)=.32$, n.s. $]$.

Conversely, $\mu$ opiate receptor binding was significantly altered by exposure to shock. A two-way MANOVA demonstrated a significant effect of group on naloxone binding $[F(6,104)=2.81, p<.05]$. Subsequent two-way ANOVAs in each hippocampal field revealed a significant effect of treatment in CA3 only [for CA3, $F(2,54)=$ $4.80, p<.05$; for $\mathrm{CAl}, F(2,54)=2.42$, n.s.; for the dentate gyrus, $F(2,54)=0.33$, n.s.]. This effect did not vary across layers [for treatment $\times$ layer interaction: for CA 1 ,
$F(4,54)=0.40$, n.s.; for CA3, $F(4,54)=0.28$, n.s.; for the dentate gyrus, $F(4,54)=0.64$, n.s.].

Post hoc analyses revealed that $\left[{ }^{3} \mathrm{H}\right]$ naloxone binding was significantly decreased in CA 3 of the US rats, as com-
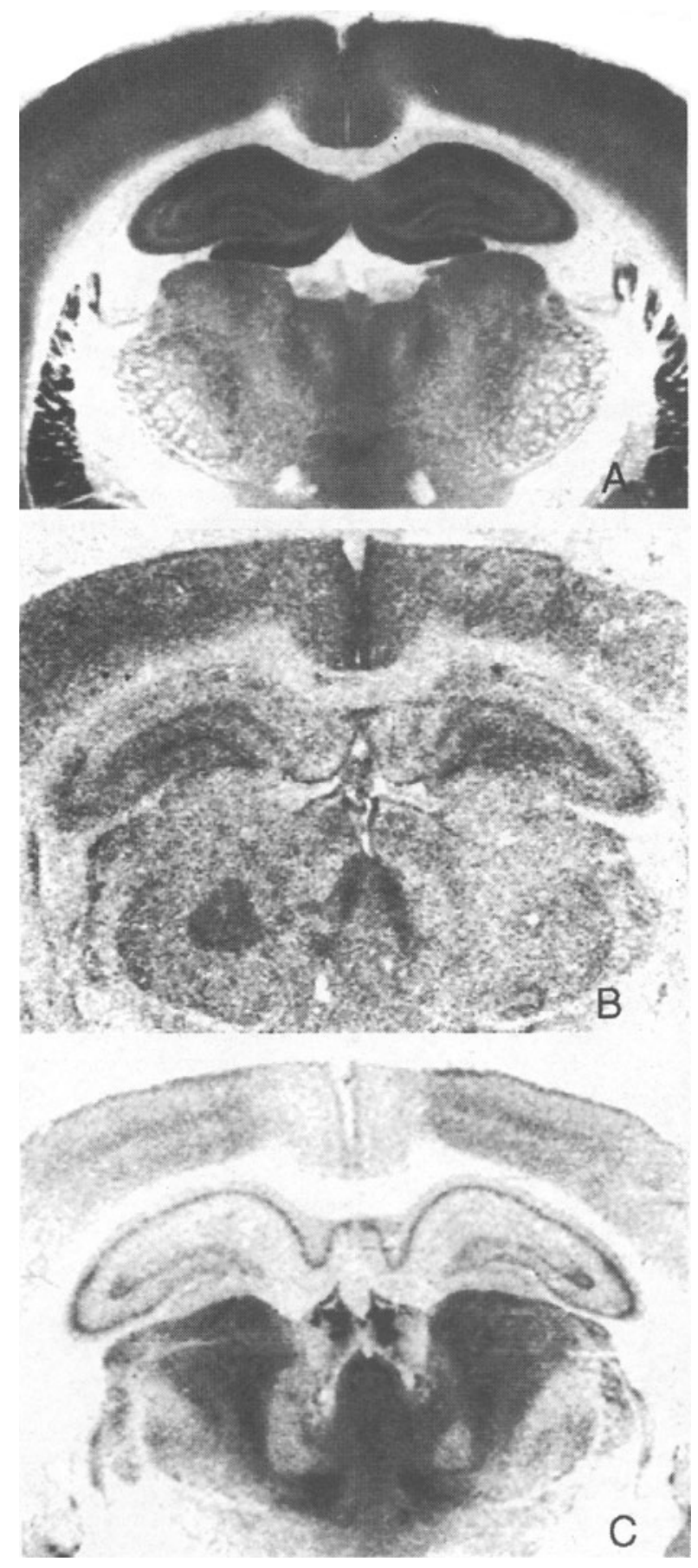

Figure 2. Digitized images of binding of (A) $\left[{ }^{3} \mathrm{H}\right] \mathrm{QNB}$, (B) $\left[^{3} \mathrm{H}\right] \mathrm{DMI}$, and $(\mathrm{C})\left[{ }^{3} \mathrm{H}\right]$ naloxone in the hippocampus visualized with in vitro autoradiography. All images are taken from the same animal, which received no shock (NS group). 

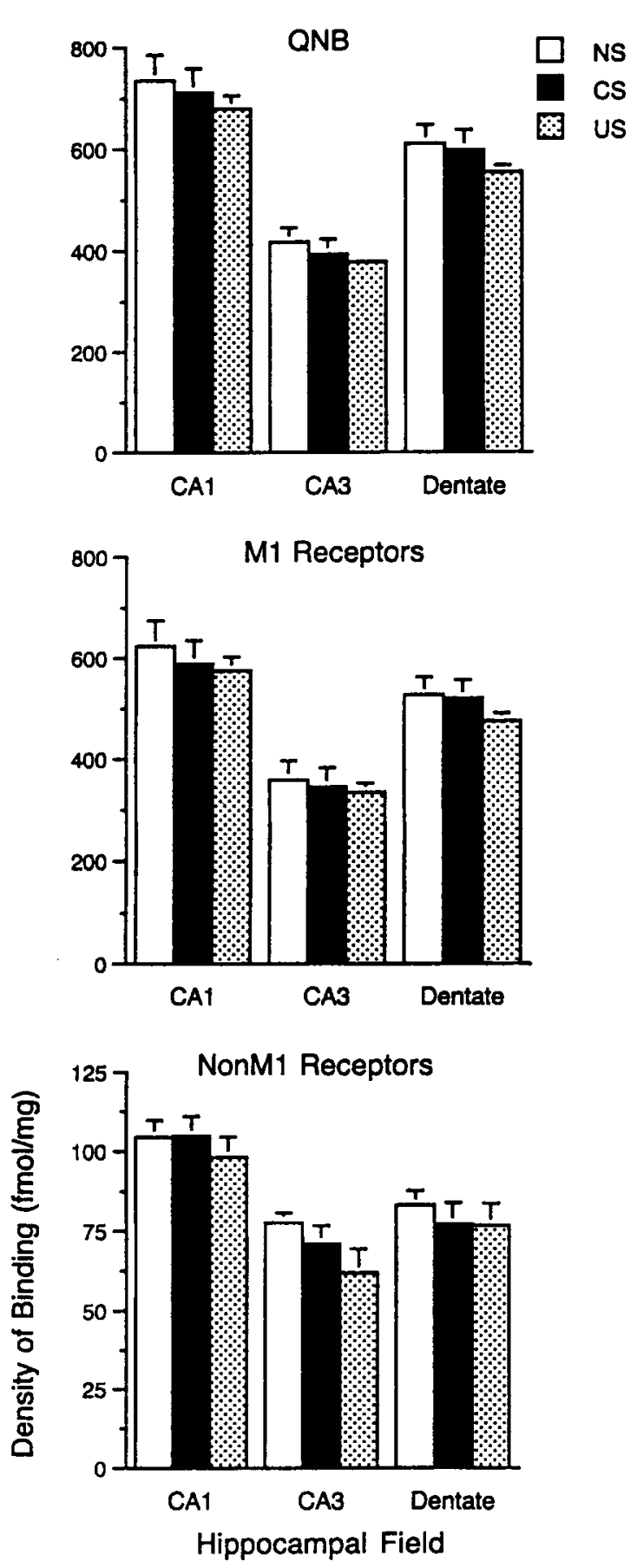

Figure 3. Mean specific $\left[{ }^{3} H\right] Q N B, M_{1}$ receptor, and non- $M_{1}$ receptor binding ( $\mathrm{fmol} / \mathrm{mg}$ wet tissue weight) in hippocampal areas $\mathrm{CA1}, \mathrm{CA3}$, and the dentate gyrus for rats receiving no shock (NS), controllable shock (CS), or uncontrollable shock (US). Vertical bars represent error bars.

pared with either the CS or the NS rats $[t(13)=12.15$ and $t(13)=10.40$, respectively, $p<.05]$, whereas binding in $\mathrm{CA} 3$ of the CS rats did not differ significantly from that of the NS rats. Overall, $\left[{ }^{3} \mathrm{H}\right]$ naloxone binding in CA3 of the US rats was decreased $15 \%$ relative to the NS rats and
$18 \%$ relative to the CS rats. In the pyramidal cell layer of $\mathrm{CA} 3$, the US rats demonstrated decreases of $15 \%$ and $16 \%$ relative to the NS and CS rats; in the stratum oriens, $\left[{ }^{3} \mathrm{H}\right]$ naloxone binding was decreased $22 \%$ and $21 \%$ relative to the NS and CS rats; and in the stratum radiatum, $\left[{ }^{3} \mathrm{H}\right]$ naloxone binding was decreased $10 \%$ and $16 \%$ relative to the NS and CS rats (Figure 5).

\section{DISCUSSION}

Exposure to chronic, uncontrollable shock significantly impaired subsequent learning of an escape response. US rats showed significantly longer escape latencies on FR2 but not FR1 trials of a shuttle-escape task. This pattern of performance on the escape task is consistent with previous studies: Robust controllability effects are typically seen only when the escape task is made more difficult by using an FR2 schedule of reinforcement (see, e.g., Brannan, Miller, Jones, Kramer, \& Petty, 1995; Drugan, Skolnick, Paul, \& Crawley, 1989; Maier, Albin, \& Testa, 1973; Petty, Chae, Kramer, Jordan, \& Wilson, 1994; Petty, Kramer, Wilson, \& Jordan, 1994). In contrast, exposure to chronic, controllable shock had no effect on subsequent learning of the escape response. The escape latencies of rats receiving controllable shock did not differ from those of animals receiving no shock, whereas the escape latencies of rats receiving uncontrollable shock were significantly longer than those of rats receiving no shock and of rats who could control the shock. Thus, as in previous studies, uncontrollable shock produced learned helplessness, whereas ability to control the shock prevented learned helplessness (see, e.g., Seligman \& Maier, 1967).

Quantitative autoradiography revealed significant decreases in $\mu$ opiate receptor binding in the CA3 field of

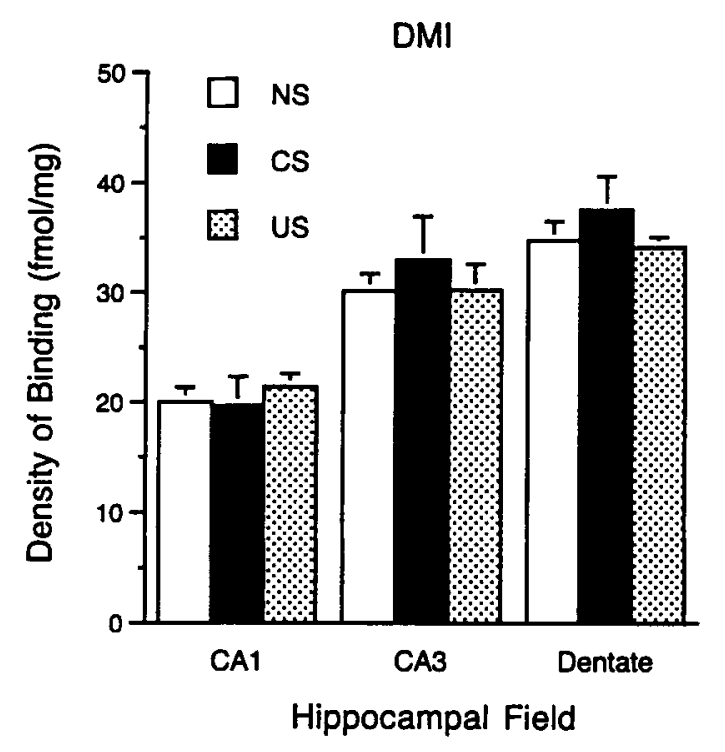

Figure 4. Mean specific [ ${ }^{3} \mathrm{H} \mid \mathrm{DMI}$ binding ( $\mathrm{fmol} / \mathrm{mg}$ wet tissue weight) in hippocampal areas $\mathrm{CA1}, \mathrm{CA3}$, and the dentate gyrus for rats receiving no shock (NS), controllable shock (CS), or uncontrollable shock (US). Vertical bars represent error bars. 

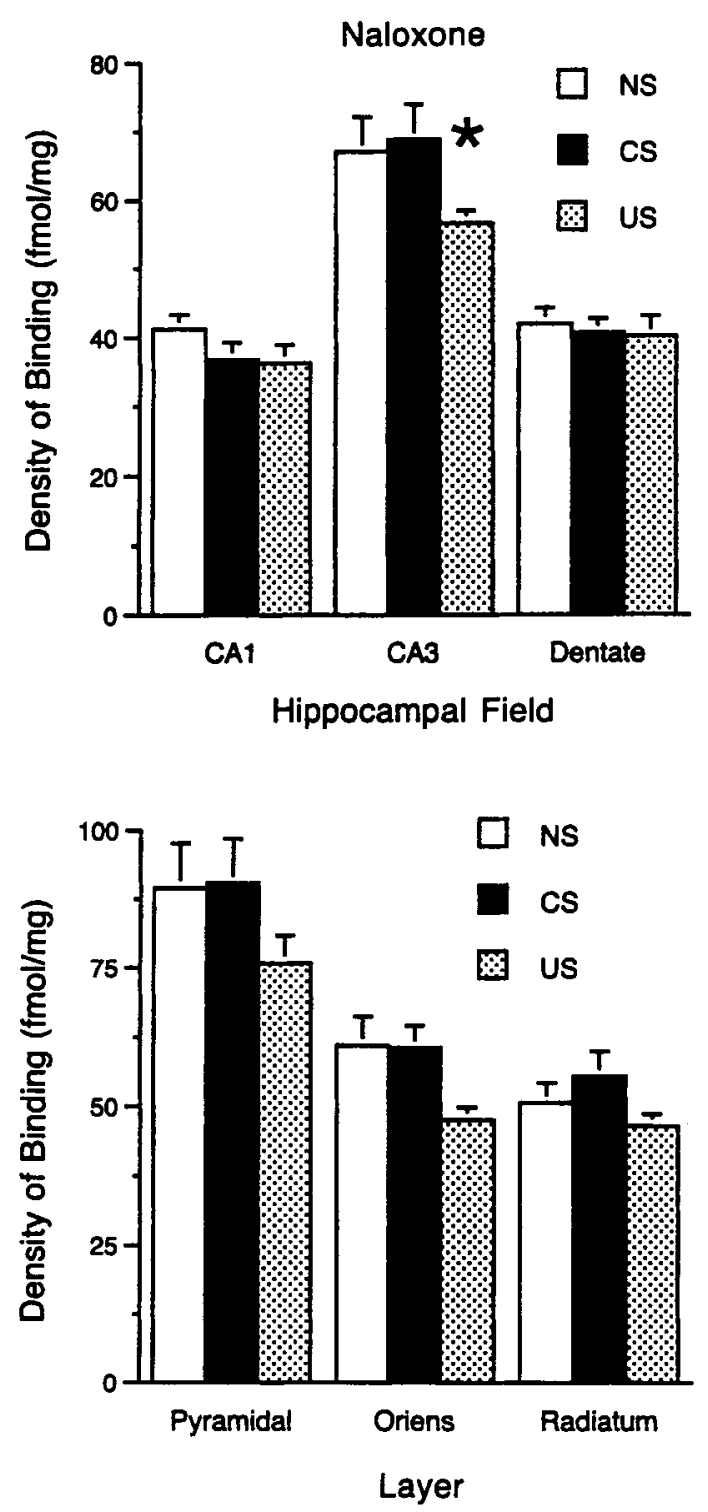

Figure 5. Top: Mean specific [ $\left.{ }^{3} \mathrm{H}\right]$ naloxone binding ( $\mathrm{fmol} / \mathrm{mg}$ wet tissue weight) in hippocampal areas $\mathrm{CA1}, \mathrm{CA3}$, and the dentate gyrus for rats receiving no shock (NS), controllable shock (CS), or uncontrollable shock (US). Bottom: Mean $\left[{ }^{3} \mathrm{H}\right]$ naloxone binding ( $\mathrm{fmol} / \mathrm{mg}$ wet tissue weight) in the pyramidal layer, stratum oriens, and stratum radiatum of area CA3 for NS, CS, and US rats. Vertical bars represent error bars. Asterisk indicates a significant difference from NS and CS groups $(p<.05)$.

the hippocampus in animals receiving uncontrollable shock. In contrast, no changes in noradrenergic uptake and in muscarinic and $\mu$ opiate receptor binding were found in the hippocampus of animals receiving controllable shock. Thus, the ability to control shock prevented stress-induced changes in the endogenous opiate system in the hippocampus.

In contrast to previous studies, muscarinic cholinergic receptor binding was not affected by uncontrollable shock. Previous studies using immobilization stress have demon- strated up-regulation of muscarinic receptors after both acute (see, e.g., Mizukawa et al., 1989) and chronic (Finkelstein et al., 1985) uncontrollable stress. However, differences in the nature of the stressor (immobilization vs. shock) may account for such a discrepancy. For instance, others have failed to find alterations in hippocampal $\beta$ adrenergic receptor binding after acute tailshock (Brannan et al., 1995), despite several previous reports of increased $\beta$-adrenergic receptor binding after inescapable footshock (see, e.g., Martin et al., 1990). Indeed, although several studies have documented alterations in presynaptic cholinergic activity after immobilization stress (see, e.g., Finkelstein et al., 1985), others have failed to detect alterations in presynaptic cholinergic activity following uncontrollable shock (see, e.g., Geoffroy, Tvede, Christensen, \& Schou, 1991). Thus, hippocampal muscarinic receptors may be differentially sensitive to immobilization as opposed to shock stress.

In the present study, we failed to detect alterations in noradrenergic reuptake in rats receiving either controllable or uncontrollable shock. Previous studies have shown alterations in hippocampal norepinephrine release (see, e.g., Hellhammer, Rea, Bell, Belkien, \& Ludwig, 1984; Petty et al., 1993) and in $\beta$-adrenergic receptor binding (see, e.g., Martin et al., 1990) after exposure to uncontrollable shock. Thus, uncontrollable stress may differentially affect release or receptor binding, whereas reuptake is apparently not affected. Alternatively, Petty and colleagues found decreased $\mathrm{K}^{+}$-evoked norepinephrine release only in those rats that were exposed to uncontrollable shock and that demonstrated learned helplessness; those rats that were exposed to uncontrollable shock but did not demonstrate learned helplessness did not show deficits in $\mathrm{K}^{+}$-evoked norepinephrine release. In the present study, we did not assess behavioral deficits and pharmacological alterations in the same rats. Thus, potential differences in both noradrenergic uptake and muscarinic receptor binding in only those rats demonstrating learned helplessness may not have been detected. Assessment of these measures in rats characterized as either helpless or nonhelpless will clarify this issue.

Despite consistency across groups in binding to noradrenergic uptake sites and muscarinic receptors, $\mu$ opiate receptor binding was significantly decreased by up to $22 \%$ in area CA 3 of those rats receiving uncontrollable shock. This finding is consistent with previous studies that document a role for the opiate system in the hippocampal stress response (see, e.g., Shors et al., 1990; TejedorReal et al., 1995). Our preliminary analyses of other areas (for instance, medial prefrontal cortex) show no significant stress-induced changes in $\mu$ opiate receptor binding, suggesting that the effects that we see in the hippocampal opiate system are not generalized throughout the nervous system. Furthermore, the specificity of the effect within the hippocampus is also consistent with previous findings. For instance, chronic restraint stress has been shown to result in atrophy of the apical dendrites of CA3 pyramidal neurons (Watanabe et al., 1992). Additionally, 
Luine and colleagues (Luine et al., 1994) found that chronic restraint stress impaired learning-dependent increases in serotonin levels in CA3 but not in CA1 or the dentate gyrus. Finally, the work of both Finkelstein et al. (1985) and Mizukawa et al. (1989) suggests that stressinduced alterations in hippocampal pharmacology vary across time as well as across hippocampal areas.

Alternatively, studies have found changes in the physiology of both CAl (Shors et al., 1989) and the dentate gyrus (Henke, 1990) after chronic, inescapable stress. Although we found no changes in $\mu$ opiate receptor binding in area $\mathrm{CA} 1$ in the present study, the $\mu$ opiate receptor changes in CA3 may be partially responsible for changes in the physiology of CAl via intrahippocampal projections. For instance, a portion of the mossy fiber pathway from the dentate gyrus to area CA3 appears to be opiatergic (Gall et al., 1981). Thus, alterations in opiatergic neurons in the dentate gyrus could affect $\mu$ opiate receptors in CA3 and, ultimately, the activity of CA1 via Schaffer collaterals (Amaral \& Witter, 1989). Indeed, iontophoretic application of enkephalin and glutamate, combined with intracellular recording from hippocampal pyramidal cells, suggests that opiate receptors are localized on inhibitory interneurons and that activation of these receptors disinhibits pyramidal cells (Madison \& Nicoll, 1988). More recently, $\mu$ opiate receptors have been shown to play a role in LTP: Application of a $\mu$ opiate agonist facilitates LTP induction, whereas application of an antagonist impairs LTP induction (Derrick \& Martinez, 1994). Thus, downregulation or decreased affinity of $\mu$ opiate receptors, reflected in the decreased $\left[{ }^{3} \mathrm{H}\right]$ naloxone binding found in the present study, may decrease the excitability of hippocampal pyramidal neurons, contributing to the alterations in hippocampal physiology that result from uncontrollable stress. Given the acceptance of hippocampal LTP as a model of learning and memory and the involvement of opiates in learning and memory (see, e.g., Gallagher et al., 1983), it is interesting to speculate that alterations in $\mu$ opiate receptors in area CA3 after exposure to uncontrollable stress may contribute to stress-induced cognitive deficits.

Finally, in the present study, the stress-induced decrease in $\mu$ opiate receptor binding in CA 3 was absent in animals that could control the stressor. This finding is consistent with previous studies demonstrating that ability to control the stressor modulates the effect of stress on hippocampal function. For instance, the ability to escape a mild shock partially reversed the impairment of LTP that resulted from exposure to inescapable shock (Shors et al., 1989). Likewise, although exposure to either escapable or inescapable shock did not alter subsequent baseline hippocampal EEG, hippocampal theta activity was suppressed after a probe shock in rats that had received inescapable shock, whereas theta activity in rats that had received escapable shock was not altered (Balleine \& Curthoys, 1991). Thus, our data, combined with previous physiological studies, indicate that, although the hippocampal opiate system is altered after chronic exposure to uncontrollable stress, this alteration is ameliorated by the ability to control the stressor.

\section{REFERENCES}

Altenor, A., KAY, E., \& Richter, M. (1977). The generality of learned helplessness in the rat. Learning \& Motivation, 8, 54-61.

AMARAL, D. G., \& WITTER, M. P. (1989). The three-dimensional organization of the hippocampal formation: A review of anatomical data. Neuroscience, 31, 571-591.

Balleine, B. W., \& Curthoys, I. S. (1991). Differential effects of escapable and inescapable footshock on hippocampal theta activity. $B e$ havioral Neuroscience, 105, 202-209.

BEAR, M. F., \& Singer, W. (1986). Modulation of visual cortical plasticity by acetylcholine and noradrenaline. Nature, 320, 172-176.

Brannan, S. K., Miller, A., Jones, D. J., Kramer, G. L., \& PetTy, F. (1995). $\beta$-adrenergic receptor changes in learned helplessness may depend on stress and test parameters. Pharmacology, Biochemistry \& Behavior, 51, 553-556.

Dalmaz, C., Introini-Collison, I. B., \& McGaugh, J. L. (1993). Noradrenergic and cholinergic interactions in the amygdala and the modulation of memory storage. Behavioural Brain Research, 58, $167-174$.

DECKER, M. W. (1992). Cholinergic/noradrenergic interactions and memory. In D. Levin, M. W. Decker, \& L. L. Butcher (Eds.), Neurotransmitter interactions and cognitive function (pp. 78-90). Boston: Birkhauser.

DerRick, B. E., \& MARTINez, J. L., JR. (1994). Opioid receptor activation is one factor underlying the frequency dependence of mossy fiber LTP induction. Journal of Neuroscience, 14, 4359-4367.

Drugan, R. C., Skolnick, P., Paul, S. M., \& Crawley, J. N. (1989). A pretest procedure reliably predicts performance in two animal models of inescapable stress. Pharmacology, Biochemistry \& Behavior, 33, 649-654.

Duncan, G. E., Paul, I. A., Fassberg, J. B., Powell, K. R., Stumpf, W. E., \& Breese, G. R. (1991). Autoradiographic analysis of the in vivo distribution of $3 \mathrm{H}$-imipramine and $3 \mathrm{H}$-desipramine in brain: Comparison to in vitro binding patterns. Pharmacology, Biochemistry \& Behavior, 38, 621-631.

Finkelstein, Y., Koffler, B., Rabey, J. M., \& Gilad, G. M. (1985). Dynamics of cholinergic synaptic mechanisms in rat hippocampus after stress. Brain Research, 343, 314-319.

Gall, C., Brecha, N., Karten, H., \& Chang, K. J. (1981). Localization of enkephalin-like immunoreactivity in identified axonal and neuronal populations of the rat hippocampus. Journal of Comparative Neurology, 198, 335-350.

Gallagher, M., King, R. A., \& Young, N. B. (1983). Opiate antagonists improve spatial memory. Science, 221, 975-976.

Gallagher, M., RaPp, P. R., \& Fanelli, R. J. (1985). Opiate antagonist facilitation of time-dependent memory processes: Dependence upon intact norepinephrine function. Brain Research, 347, 284-290.

GEARY, W. A., \& WoOTEN, G. F. (1983). Quantitative film autoradiography of opiate agonist and antagonist binding in rat brain. Journal of Pharmacology \& Experimental Therapeutics, 225, 234-240.

Geoffroy, M., Tvede, K., Christensen, A. V., \& Schou, J. S. (1991). The effect of imipramine and lithium on "learned helplessness" and acetylcholinesterase in rat brain. Pharmacology, Biochemistry \& Behavior, 38, 93-97.

GERlaCH, J., \& McEwEN, B. (1972). Rat brain binds adrenal steroid hormone: Radioautography of hippocampus with corticosterone. Science, 175, 1133-1136.

Hellhammer, D. H., Rea, M. A., Bell, M., Belkien, L., \& LudWIG, M. (1984). Learned helplessness: Effects on brain monoamines and the pituitary-gonadal axis. Pharmacology, Biochemistry \& Behavior, 21, 481-485. 
Henke, P. G. (1990). Granule cell potentials in the dentate gyrus of the hippocampus: Coping behavior and stress ulcers in rats. Behavioural Brain Research, 36, 97-103.

Herkenham, M., \& Pert, C. B. (1980). In vitro autoradiography of opiate receptors in rat brain suggests loci of "opiatergic" pathways. Proceedings of the National Academy of Sciences, 77, 5532-5536.

KELSEY, J. E., \& BAKER, M. D. (1983). Ventromedial septal lesions in rats reduce the effects of inescapable shock on escape performance and analgesia. Behavioral Neuroscience, 97, 945-961.

KRUGLIKOV, R. I. (1982). On the interaction of neurotransmitter systems in processes of learning and memory. In C. A. Marsan \& H. Matthies (Eds.), Neuronal plasticity and memory formation (pp. 339-351). New York: Raven.

Luine, V., Villegas, M., Martinez, C., \& McEwen, B. S. (1994). Stress-dependent impairments of spatial memory: Role of 5-HT. In E. R. de Kloet, E. C. Azmitia, \& P. W. Landfield (Eds.), Brain corticosteroid receptors: Studies on the mechanism, function, and neurotoxicity of corticosteroid action (Annals of the New York Academy of Sciences, Vol. 746, pp. 403-404). New York: New York Academy of Sciences.

MAdison, D. V., \& NiCOLl, R. A. (1988). Enkephalin hyperpolarizes interneurones in the rat hippocampus. Journal of Physiology, 398, 123130.

Maier, S. F., Albin, R. W., \& Testa, T. J. (1973). Failure to learn to escape in rats previously exposed to inescapable shock depends on nature of escape response. Journal of Comparative \& Physiological Psychology, 85, 581-592.

Martin, J. V., Edwards, E., Johnson, J. O., \& Henn, F. A. (1990). Monoamine receptors in an animal model of affective disorder. Journal of Neurochemistry, 55, 1142-1148.

Minor, T. R., Pelleymounter, M. A., \& Maier, S. F. (1988). Uncontrollable shock, forebrain norepinephrine, and stimulus selection during choice-escape learning. Psychobiology, 16, 135-145.

Mizukawa, K., Takayama, H., Sato, H., Ota, Z., Haba, K., \& OGAWA, N. (1989). Alterations of muscarinic cholinergic receptors in the hippocampal formation of stressed rat: In vitro quantitative autoradiographic analysis. Brain Research, 478, 187-192.

NonAKA, R., \& MoROJI, T. (1984). Quantitative autoradiography of muscarinic cholinergic receptors in the rat brain. Brain Research, 296, 295-303.

Overmier, J. B., \& Seligman, M. E. P. (1967). Effects of inescapable shock upon subsequent escape and avoidance responding. Journal of Comparative \& Physiological Psychology, 63, 28-33.

Pasternak, G. (1987). Opioid receptors. In H. V. Meltzer (Ed.), Psy- chopharmacology: The third generation of progress (pp. 281-288). New York: Raven.

Petty, F., Chae, Y.-L., Kramer, G., Jordan, S., \& Wilson, L. (1994). Learned helplessness sensitizes hippocampal norepinephrine to mild restress. Biological Psychiatry, 35, 903-908.

Petty, F., Kramer, G., Wilson, L., \& Chae, Y.-L. (1993). Learned helplessness and in vivo hippocampal norepinephrine release. Pharmacology, Biochemistry \& Behavior, 46, 231-235.

PetTy, F., Kramer, G., Wilson, L., \& Jordan, S. (1994). In vivo serotonin release and learned helplessness. Psychiatry Research, 52 , 285-293.

RAPP, P. R. (1986). The effects of age on spatial information processing: Relationship to senescent changes in brain noradrenergic and opioid systems (Doctoral dissertation, University of North Carolina, Chapel Hill, 1985). Dissertation Abstracts International, 47, 87B.

RoselLINI, R. A. (1978). Inescapable shock interferes with the acquisition of a free appetitive operant. Animal Learning \& Behavior, 6 , 155-159.

Rosellini, R. A., \& DeCola, J. P. (1981). Inescapable shock interferes with the acquisition of a low-activity response in an appetitive context. Animal Learning \& Behavior, 9, 487-490.

Seligman, M. E. P., \& Maier, S. F. (1967). Failure to escape traumatic shock. Journal of Experimental Psychology, 74, 1-9.

SERVATIUS, R. J., \& SHORS, T. J. (1994). Exposure to inescapable stress persistently facilitates associative and nonassociative learning in rats. Behavioral Neuroscience, 108, 1101-1106.

Shors, T. J., LeVINE, S., \& Thompson, R. F. (1990). Opioid antagonist eliminates the stress-induced impairment of long-term potentiation (LTP). Brain Research, 506, 316-318.

Shors, T. J., Seib, T. B., Levine, S., \& Thompson, R. F. (1989). Inescapable versus escapable shock modulates long-term potentiation in the rat hippocampus. Science, 244, 224-226.

Shors, T. J., Weiss, C., \& Thompson, R. F. (1992). Stress-induced facilitation of classical conditioning. Science, 257, 537-539.

Tejedor-Real, P., Mico, J. A., Maldonado, R., Roques, B. P., \& GiberT-RAHOLA, J. (1995). Implication of endogenous opioid system in the learned helplessness model of depression. Pharmacology, Biochemistry \& Behavior, 52, 145-152.

Watanabe, Y., Gould, E., \& McEwen, B. S. (1992). Stress induces atrophy of apical dendrites of hippocampal CA3 pyramidal neurons. Brain Research, 588, 341-345.

(Manuscript received September 22, 1997; revision accepted for publication December 22, 1997.) 